\title{
MicroRNA-126 Regulates the Expression of Stem Cell Transcription Factors (Sox2 and Lin28) in Various Ovarian Tumors
}

Ho Park and Seung Joo Jekal

Department of Clinical Laboratory Science, Wonkwang Health Science University, Iksan 54638, Korea

\section{MicroRNA-126은 난소 종양세포의 줄기세포 전사인자 (Sox2와 Lin28) 발현을 조절한다}

\author{
박 호, 제갈승주 \\ 원광보건대학교 임상병리과
}

\begin{abstract}
Stem cell-like tumor cells are reported to be the main reason for tumor recurrence and metastasis. As one of the new approaches to overcome cancer, studies are emerging to inhibit the expressions of stem cell transcriptional factors (Oct4, Sox2, Klf-4, and Lin28) in cancer cells. MicroRNAs are master genetic regulators that can control development and differentiation of stem cells. In this study using various ovarian tumors (Skov3, Ovcar3, Tov112D, Tov21G, PA-1 and Hsc832(c)T), we examined the expressions of stem cell-related transcription factors, and the biological changes in cell survival and growth by miR-126that targets stem cell transcriptional factors. We observed that treatment of miR-126 induced the morphological changes and cell suspension in most cells. In addition, miR-126 induced gradual regression of cell division except Skov3 cells, especially significant time-dependent reduction in Tov112D, Tov21G and PA-1. When we examined the expression of stem cell transcriptional factors, Sox2 was shown to be down-regulated after miR-126. Our results demonstrate that miR-126treatment can provide the reversible environment to regulate cell division and to induce cell death of ovarian tumors, suggesting the molecular biological clues for clinical usage.
\end{abstract}

Keywords: Stem cell, Transcription factors, MiR-126, Ovarian tumors, Cell division, Cell death

This is an Open Access article distributed under the terms of the Creative Commons Attribution Non-Commercial License (http://creativecommons.org/licenses/by-nc/4.0) which permits unrestricted non-commercial use, distribution, and reproduction in any medium, provided the original work is properly cited.

Copyright ( 2015 The Korean Society for Clinical Laboratory Science. All rights reserved.
Corresponding author: Ho Park

Department of Clinical Laboratory Science,

Wonkwang Health Science University, Iksan 54638, Korea

Tel: 82-63-840-1214

E-mail: bacoya@naver.com

Received: November 1, 2015

Revised $1^{\text {st: }}$ November 13,2015

Revised 2 ${ }^{\text {nd. }}$ : November 20, 2015

Revised $3^{\text {rd: }}$ : November 22, 2015

Revised $4^{\text {th }}$ : November 23, 2015

Revised 5 ${ }^{\text {th }}$ : November 25, 2015

Revised 6 ${ }^{\text {th }}$ : November 26, 2015

Revised $7^{\text {th }}$ : November 26, 2015

Accepted: November 26, 2015

\section{서 론}

마이크로 RNA (microRNA, miRNA, 이하 microRNA)는 핵 내 primary miRNA (pri-miRNA)가 RNase III type 효소인 Drosha
에 의해 precursor miRNA (pre-miRNA) (80 90 nt)로 절단된 후 세포질로 이동하여 Dicer라는 효소에 의해 만들어지는 21 25nt 크기의 작은 RNA이다. MicroRNA는 세포질에 존재하면서 특정 $\mathrm{mRNA}$ 의 3'-UTR (untranslated regions)과 결합하여 특정 유전 
자의 발현을 특이적으로 억제할 수 있다(Williams 등 2008; Eulalio 등, 2009). 뿐만 아니라 target mRNA의 변성(degradation)을 유도하여 해당 $\mathrm{mRNA}$ 로부터 단백질 합성을 저해, 즉 전사 후 유전자 발현 억제(post-transcriptional gene silencing)기전을 통해 유전자 발현 조절에 관여하여, 분화와 분열 및 사멸 등의 생체 내 새로운 형태의 유전적 발현 조절 분자로서 이를 이용한 분자치 료제 개발이 이루어지고 있다(Li 등, 2008). 최근 발생학적 개념을 이용하여 종양세포 및 종양줄기세포에 대한 실험적 접근이 점차 증 가하고 있음을 고려해볼 때 발생학적으로 의미 있는 암세포의 미분 화 전사인자(stem cell transcription factor)를 표적(targeting)하 여 종양세포의 분열억제와 세포 사멸을 유도하는 연구가 증가하고 있다(Sales 등, 2007; Ittai 등, 2008; Otsubo T 등, 2011).

본 실험에 이용된 microRNA-126은 혈관과 세포 이동을 조절 하는 EGFL7(Saito 등, 2009; Sun 등, 2010), 세포 신호경로와 세포 의 분열, 점착 침투를 조절하는 $C r K$ (Crawford 등, 2008), 종양의 생존과 사멸에 관련된 $V E G F-A$ (Liu 등, 2009), 세포주기 G1 S phase에 관련된 IRS-1 (Zhang 등, 2008) 그리고 HOXA9같이 개 체 발달에 중요한 유전자를 표적 조절하는 것으로 보고되어 있다 (Shen 등, 2008). 또한 microRNA-126은 acute myeloid leukemia에서 과발현 되어있고 colorectal cancer (Li 등, 2011), lung cancer (Liu 등, 2009) 에서 발현이 감소된 경향을 보이는 것으로 보고되고 있으며, 최근 microRNA-126은 난소종양세포에서 $P A K$ 늘 표적하여 세포주기인자를 조절하는 연구가 보고되었다 (Luo 등, 2015). 하지만 아직까지 난소종양세포에서 미분화 전사인 자와의 관련 연구는 전무하다.

전 세계적으로 여성 암 중에서 난소암은 다른 종양에 비해 전이 와 재발 능력이 높을 뿐만 아니라 항암제 내성이 높아, 5 년 생존율 이 30 40\%밖에 되지 않는 것으로 보고되고 있다(Ann 등, 2014). 특히 난소기관은 생식적으로 미분화와 연관성이 높은 장기로 세포 내 주변 환경(호르몬, 사이토카인 등 외부 또는 내부 미세환경)에 의 해 민감한 영향을 받는 세포 조직이다(Peng 등, 2010). 따라서 본 실험에서는 다양한 난소 종양세포를 이용하여 줄기세포가 가지는 미분화 전사인자의 발현 분석과 이를 표적으로 하는 microRNA1260 이 난소 종양세포들의 세포 분열능력과 사멸유도에 어떠한 영 향을 미치는지에 대한 분자생물학적 단서를 제공하고자 한다.

\section{재료 및 방법}

\section{1. 다양한 난소 종양세포 배양}

각 특성에 따른 난소 종양세포주 6종(양성 1종, 악성 5종)을 성균 관대학교 의과대학 성체줄기세포연구소로부터 분양 받아(Table 1) 원심 분리한 후 상층액을 제거하고, 침전된 세포를 Dulbecco's Modified Eagle's medium (DMEM), 10\% fetal bovine serum (FBS), $1 \%$ antibiotic/antimycotic solution에 넣어 부유한 후 T75 플라스크에 분리한 세포를 넣고 $5 \% \mathrm{CO}_{2}$ 가 공급되는 $37^{\circ} \mathrm{C}$ incubator에서 배양하였다. 다음날 세포 모양을 관찰해서 세포 부유 물이 있을 경우 phosphate-buffered saline (PBS)로 수세하였고, 세포배양액을 2 3일에 한 번씩 교체하였다. 각 종양세포가 플라 스크에 $80 \%$ 될 때까지 배양한 후 실험에 이용하였다.

\section{2. microRNA의 형질 주입}

세포 내에 microRNA-126을 전달하기 위해 형질 주입 혼합물 (microRNA-126+ PBS + G-Fectin)을 준비하였다. 혼합물은 10 분간 실온에서 반응을 유도하였다. 반응된 형질주입 혼합물은 각 well당 $4 \times 10^{4}$ 으로 분주된 난소 종양세포에 처리하였다. MicroRNA-126sequencer (Genolution Pharmaceuticals Co., Seoul, Korea)와 G-Fectin (Genolution Pharmaceuticals Co., Seoul, Korea)을 사용하여 분석하였다(Table 2).

\section{3. 광학현미경적 세포 형태 관찰}

난소 종양세포에 scramble과 microRNA-126을 처리한 후 3일 과 7일에 CK2 위상차현미경(Olympus Co., Tokyo, Japan)을 이 용하여 $100 X$ 에서 난소 종양세포의 형태학적 분석을 수행하였다.

Table 1. Culture of various ovarian tumor cells

\begin{tabular}{cll}
\hline NO & Cell line name & \multicolumn{1}{c}{ Cancer type } \\
\hline 1 & HSC832(c)T & Benign ovary cyst, endometriosis \\
2 & OVCAR3 & Ovarian adenocarcinoma cell lines \\
3 & Tov21G & Ovary clear cell carcinoma \\
4 & Tov112D & Endometrioid carcinoma \\
5 & Skov3 & Ovary serous adenocarcinoma \\
6 & PA-1 & Ovary teratocarcinoma \\
\hline
\end{tabular}

Table 2. Transfection of microRNA and scramble (negative control)

\begin{tabular}{cclccc}
\hline No & siRNA miRNA name & & Duplex sequence & Molecular weight & Distilled water \\
\hline 1 & Negative control & Sense & 5'ACGUGACACGUUCGGAGAAUU 3' & 6736.2 & $500 \mu \mathrm{L}$ \\
& & Antisense & 5'UUCUCCGACGUGUCACGUUU 3' & 6587.2 & \\
2 & hsa-microRNA-126 & Sense & 5'UCGUACGUGAGUAAUAAUGCG 3' & 7042.4 & $500 \mu \mathrm{L}$ \\
& & Antisense & 5'CGCAUUAUUACUCACGGUACGA 3' & 6962.4 & \\
\hline
\end{tabular}




\section{4. 세포 분열능력 분석(CCK8)}

난소 종양세포에 scramble과 microRNA-126 처리 후 각 72, 96, 120과 144시간 CCK8 세포계수 키트(Dojindo Co., Tokyo, Japan)을 이용하여 세포분열능을 분석하였다. 종양세포 배양액을 버린 후 PBS로 세척하고 CCK8 [tetrazolium salt (WST-8[2-<2methoxy-4-nitrophenyl >-3-(4-nitrophenyl)-5-(2,4disulfophenyl)-2H-tetrazolium, monosodium salt]을 control media에 1:20으로 혼합한 후 각 배양 플라스크에 처리하였다. 약 1 시간 동안 $37^{\circ} \mathrm{C}, 5 \% \mathrm{CO}_{2}$ 에 배양한 후 Enzyme-linked immunosorbent assay reader 680 (Bio-rad Co., Califonia, USA)를 이용 하여 $450 \mathrm{~nm}$ 에서 측정하였다.

\section{5. 줄기세포 전사인자 발현 분석(RT-PCR)}

실험에 이용된 total cellular RNA는 TRIzol@ Reagent (Invitrogen Co., Carlsbad, CA, USA) 를 사용하여 세포에서 분리하 였다. TRIzol $1 \mathrm{~mL}$ 를 넣고 실온에서 10분간 정지한 후 chloroform (Sigma, St. Louis, MO, USA) $0.2 \mathrm{~mL}$ 를 첨가하여 15초간 흔들어 준 후 10 분간 실온에 보관하였다. $4^{\circ} \mathrm{C}$ 에서 원심분리 $(12,000 \mathrm{rpm}$, 15 분)한 후 상층액을 채취하여 isopropyl alcohol (Sigma Co., St. Louis, USA) $0.5 \mathrm{~mL}$ 를 첨가하여 RNA를 침전시켰다. $4^{\circ} \mathrm{C}$ 에서 원심 분리(12,000 rpm, 10분)하여 상층액을 제거하고 $75 \%$ 에탄올 1 $\mathrm{mL}$ 를 첨가하여 RNA 침전물을 세척하고 $4^{\circ} \mathrm{C}$ 에서 원심분리 $(10,000$ $\mathrm{rpm}, 5$ 분)하여 상층액을 제거하였다. 침전물을 건조시킨 후 $\mathrm{DEPC}$ (diethyl pyrocarbonate) treated water (Bioline Co., London, $\mathrm{UK})$ 에 RNA 침전물을 녹여 $-70^{\circ} \mathrm{C}$ 에 보관하였다. $\mathrm{CDNA}$ 는 total $\mathrm{RNA} 3 \mu \mathrm{g}$ 을 $75^{\circ} \mathrm{C}$ 에서 5 분간 변성을 시킨 후 $5 \times$ reaction buffer, MMLV reverse transcriptase, RNAsin Ribonuclease inhibitor (Promega Co., Madison, WI, USA), 50 uM oligo-dT (Invitrogen Co., Carlsbad, CA, USA), 2.5 mM dNTP (Takara Co., Tokyo, Japan)를 사용하여 $37^{\circ} \mathrm{C}$ 에서 90 분간 역전사 반응을 유도하였다. 역전사 반응으로 합성된 $\mathrm{cDNA}$ 에서 미분화 전사인자 발현을 알아 보기 위해 primer sequence 를 제작한 후 reverse transcription polymerase chain reaction (RT-PCR)을 실시하였다(Table 3).
Premix Taq (Takara Co., Tokyo, Japan)의 TaKaRa TaqTM 1.25 units/25 $\mu$ L, dNTP 1.6 mM, pH 8.3 Tris-HCL 20 mM, KCL 100 $\mathrm{mM}, \mathrm{MgCl}_{2} 3 \mathrm{mM}$ 과 primer 20pM, cDNA $2 \mu \mathrm{g}$ 을 넣은 후 3차 증 류수를 이용하여 총 부피가 $20 \mu \mathrm{L}$ 가 되도록 하고 T professional thermocycler (Biometra Co., Gattingen, Germany)로 증폭 하였 다. 반응물은 ethidium bromide (EtBr)가 포함된 1.5\% agarose gel에서 결과를 확인하였다.

\section{결 과}

\section{MicroRNA-126은 다양한 결합부위를 가진다.}

본 실험에 이용된 microRNA-126이 난소 종양세포에 미치는 발현 조절 가능성을 평가하기 위해, 시퀀스 얼라이먼트(sequence alignment) 유전자 서열 정보 찾기(http://www.microrna.org/ hsa-microRNA-126)을 수행하였다. 최소 10 12개이상 유전분 자의 일치(sequence alignment)는 표적 유전자의 발현을 조절하 는데 상관성이 높다. 따라서 microRNA-126을 난소 종양세포에 처리시 세포주기 조절인자 $(C D K G, C D K 4, p 27$, 미분화 전사인자 (Sox2, Lin28, Klf4, C-myc)와 생존신호 경로분자(PI3K, AKT2) 는 microRNA-126의 처리에 유전적 발현 조절 가능성을 확인할 수 있다(Fig. 1).

\section{MicroRNA-126은 줄기세포 전사인자 발현을 조절할 수 있다.}

줄기세포가 가지는 미분화 전사인자를 난소 종양세포가 발현하 는지, microRNA-126처리 시 발현을 조절하는지 분석하였다. 난 소 종양세포에 S (Scramble)와 microRNA-126 (microRNA126) 처리 6일 후에 줄기세포 자가복제와 미분화성을 유지하는 중 요 전사인자 $\operatorname{Sox} 2$ 와 $\operatorname{Lin} 28$ 의 발현을 RT-PCR을 이용하여 분석하 였다. 그 결과 HSC832(t)c, Ovcar3, PA-1, Tov21G, Tov112D에서 Sox 2와 Lin28이 Scramble 보다 microRNA-126처리에서 감소 되는 것을 확인할 수 있었다. 특이하게도 Ovcar3와 Skov3는 같은 종류의 장액성 난소 선암세포(serous adenocarcinoma cells)이 지만, Skov3는 Sox2와 Lin28의 발현을 확인할 수 없었다(Fig. 2).

Table 3. List of stem cell makers

\begin{tabular}{|c|c|c|c|c|c|}
\hline No & Transcription factors & & Duplex sequence & Size & Temperature \\
\hline 1 & Sox2 & $\begin{array}{l}\text { Forward } \\
\text { Reverse }\end{array}$ & $\begin{array}{l}5,-g c a c t c t t c c a g c c t t c c t t c c-3 \\
5,-t c a c c t t c a c c g t t c c a g t t t t t-3\end{array}$ & 515 & $50^{\circ} \mathrm{C}$ \\
\hline 2 & $\operatorname{Lin} 28$ & $\begin{array}{l}\text { Forward } \\
\text { Reverse }\end{array}$ & $\begin{array}{l}\text { 5'-gcctgggcgccgagtgga-3' } \\
\text { 5'-gggcgagccgttcatgtaggtctg-3' }\end{array}$ & 443 & $66^{\circ} \mathrm{C}$ \\
\hline 3 & $\beta$-Actin & $\begin{array}{l}\text { Forward } \\
\text { Reverse }\end{array}$ & $\begin{array}{l}\text { 5'-tgtaagtggttcaacgtgcg-3' } \\
\text { 5'-ttcagcggacatgaggctac-3' }\end{array}$ & 419 & $55^{\circ} \mathrm{C}$ \\
\hline
\end{tabular}




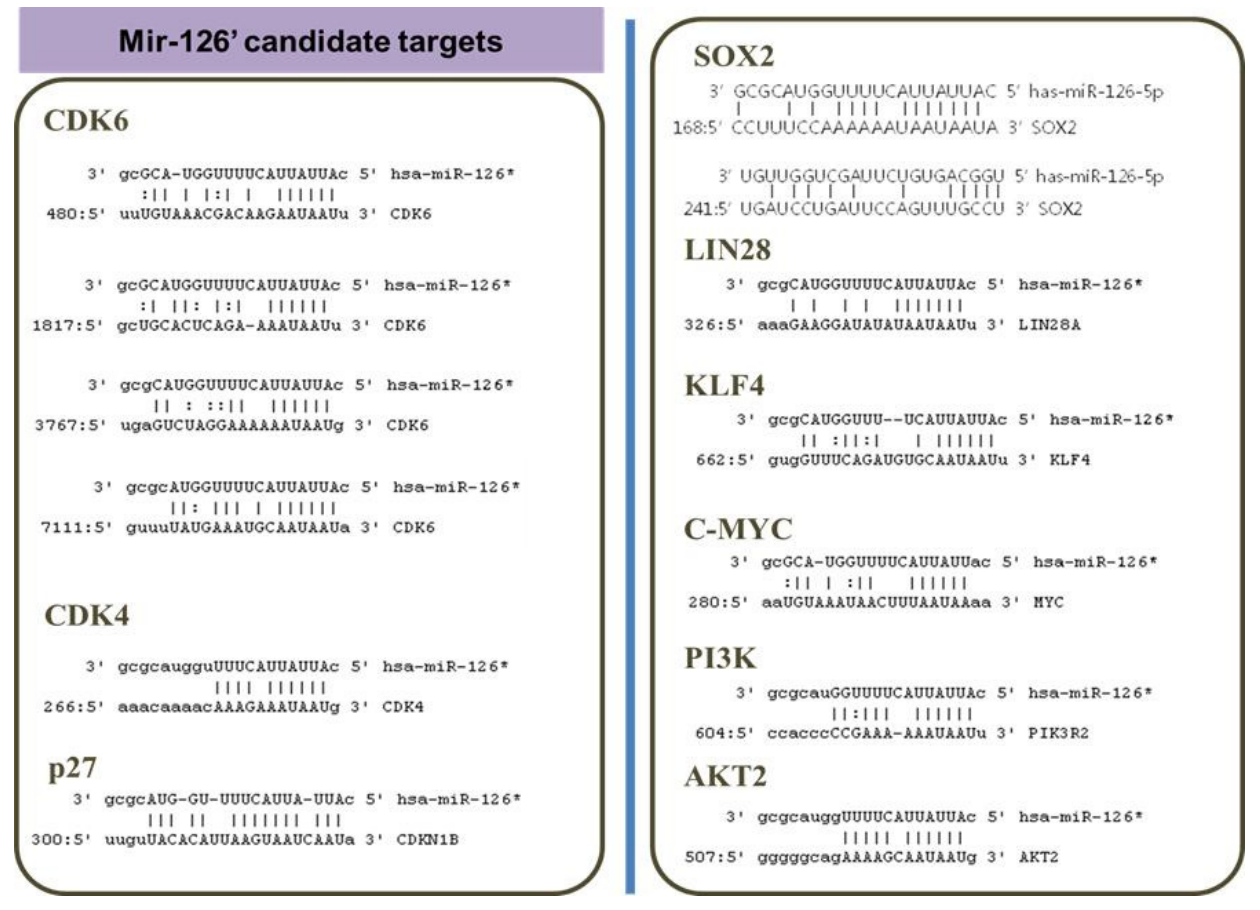

Fig. 1. MicroRNA-126 sequence alignment with cell cycle factor, cyclin dependent kinase CDK6, CDK4 and p27; transcription factor Sox2, Lin 28, Klf4 and C-myc; Survival pathway PI3K and AKT2. The target genes were also assessed RT-PCR to determine the expression level of the indicated stem cell markers.

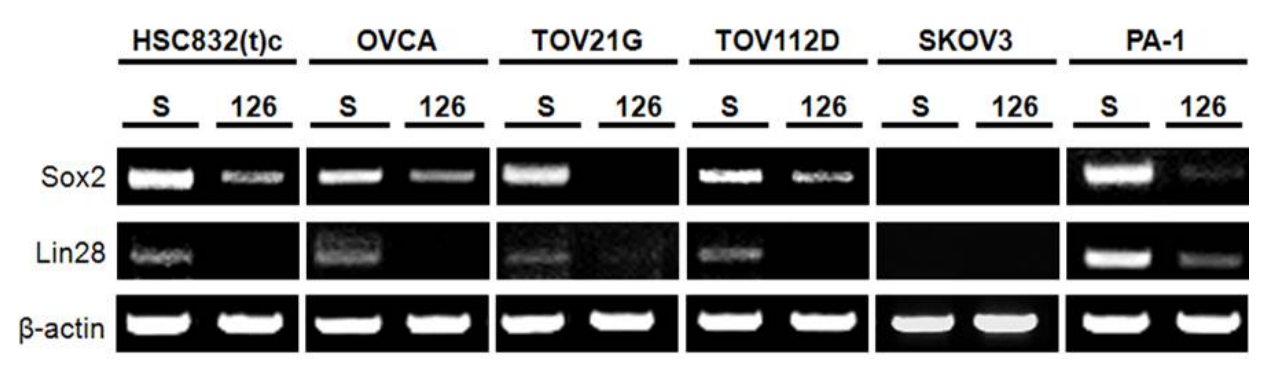

Fig. 2. Molecular marker analysis by RT-PCR after 6 days after scramble or microRNA-126 treatment. The Stem cell markers (transcription factors Sox2 and Lin28) expression were analyzed. The PCR products were resolved agarose gel and visualized by a gel documentation system after staining with $\mathrm{EtBr}$.

\section{MicroRNA-126의 처리는 난소 종양세포의 형태학적 변화를 유도한다.}

난소 종양세포 6종(Table 1)에 Scramble and microRNA-126 를 처리 후 각 72 시간에서 형태학적 현상을 관찰하였다. 그 결과 $\mathrm{HSC} 832(\mathrm{t}) \mathrm{c}$ 는 Scramble에 비해 microRNA-126에서 형태학적 변화가 3 일부터 나타나기 시작하며, 144 시간에는 분열 현상에 대 한 변화를 확실하게 관찰할 수 있었다. Skov3는 72시간에서 세포 의 형태학적 형성능력에 변화가 없어 보이지만 144 시간에서 세포 의 분열 형성능이 증가됨을 관찰할 수 있다. Ovcar3는 세포의 집단 형성 모양이 포도송이와 같은 형태를 이루며 분열을 형성해가는데 72 시간부터 분열형성을 이루지 못하고 세포사의 형태인 부유현상 을 관찰 할 수 있다. Tov21G와 Tov112D는 72시간부터 형태 변화 를 관찰 할 수 있으며, 144 시간에 세포 분열 형성이 감소되는 것을 확인할 수 있다. PA-1는 microRNA-126처리하였을 때 Ovcar3에 서처럼 민감한 형태학적 현상을 관찰할 수 있으며, 세포사의 형태
인 세포부유현상을 확인 할 수 있었다. 흥미롭게도 Skov3와 Ovcar3는 같은 장액성 난소 선암세포지만, 분열에 대한 형태학적 현상은 분명한 차이를 관찰 할 수 있었다.

\section{MicroRNA-126은 세포 분열능을 조절할 수 있다.}

MicroRNA-126처리 후 형태학적 현상에 대한 관찰결과를 정 량적으로 분석하기 위해 시간에 따라 난소 종양세포들의 분열능력 을 분석하였다. 그 결과 $\mathrm{HSC} 832(\mathrm{t}) \mathrm{c}$ 의 세포 분열능력은 Scramble 에 비해 microRNA-126처리 후 72시간에서 3배 이상 감소하였 고, 144 시간에서 6배이상 분열능력 차이를 확인할 수 있었다. Skov3의 분열능력은 72시간에서 약간 감소하였지만, 144 시간에 서 scramble과 같은 세포분열능력을 점차적으로 회복하였다. Ovcar3는 다른 종양세포에 비해 세포 분열에 대한 분열형성이 높 지 않았다. 하지만 microRNA-126처리에서 세포분열능이 scramble에 비해 감소함을 분석할 수 있었다. Tov21G와 Tov112D는 형 태학적 관찰과 비슷한 세포분열능력을 확인할 수 있었다. PA-1에 




Fig. 3. Morphology of various gynecological tumors. The cultured gynecological tumor cells were observed by optical microscopy for Cell formation and shape on 72, 144 hours after scramble and microRNA-126 treatment at the 100 fold magnitude.

microRNA-126 처리하였을 때 Ovcar3와 같은 세포분열능력의 감소를 확인할 수 있었다. 특히 PA-1과 Ovcar3에 microRNA-126 처리시 다른 세포들과는 다르게 세포사의 형태인 세포부유현상이 형태학적 관찰되었다. 이러한 현상은 세포분열능력이 감소하는 결 과와 일치하는 것으로 생각할 수 있다. 흥미롭게도 Skov3와 Ovcar3 는 같은 장액성 난소 선암세포지만, 세포분열능력에서도 상반된 결 과를 확인할 수 있었다. 이러한 결과는 형태학적 현상에서 보여준 관찰 결과와 일치한다고 생각할 수 있다(Fig. 3).

\section{고 찰}

최근 종양을 이해하고 극복하기 위한 다양한 접근법 중 하나로, 줄기세포가 잠재하고 있는 고유한 유전학적 특성(미분화 전사인 자)을 종양세포에 적용하는 실험들이 증가하고 있다. 줄기세포 전 사인자를 발현하는 종양세포(cancer stem cells 또는 tumor initiating cells)는 일반적인 종양세포에 비해 항암제 내성 및 전이, 재발과 관련이 높은 것으로 보고되고 있다(Nguyen 등, 2012). 따
라서 종양줄기세포가 발현하는 미분화 전사인자 억제 및 분화성 유 도 물질 처리는 종양세포의 미분화적 분자환경을 분화적 환경으로 유도하여 공격성 감소와 세포사멸을 유도한다고 할 수 있다 (McLean 등, 2011). 그러므로 일반적인 종양세포에서 줄기세포 전 사인자 발현은 종양의 성질을 이해하고 치료하는 중요한 지표가 될 수 있다(Viswanathan 등, 2009; Hamano 등, 2012).

본 연구에 이용된 Sox2(SRY sex-determining region Y-box 2)와 $\operatorname{Lin} 28$ 은 줄기세포만이 발현하는 고유한 전사인자로 자가 복 제, 분화유지 및 분화능에 대한 강한 잠재성을 반영하는 지표로 사 용된다(Schoenhals 등, 2009; Adachi 등, 2013). 따라서 본 연구 는 다양한 난소 종양세포에서 줄기세포 전사인자 $\operatorname{Sox} 2$ 와 $\operatorname{Lin} 28$ 의 발현을 확인하였고 그것을 표적 하는 microRNA-126을 이용하여 $S O X 2$ 와 $\operatorname{Lin} 28$ 의 발현조절을 확인할 수 있었다. 특히 microRNA126 는 $S O X 2$ 와 $P I 3 K-A K T$ pathway를 직접 표적 함으로써 종양세 포의 분열능 억제와 사멸을 유도하는 것으로 알려져 있다. 뿐만 아 니라 다양한 장기의 암종에서 $S O x 2$ 와 $\operatorname{Lin} 28$ 의 발현 억제는 항 종양 능력을 가지는 것으로 보고되고 있다(Otsubo 등, 2011; Ma 등, 

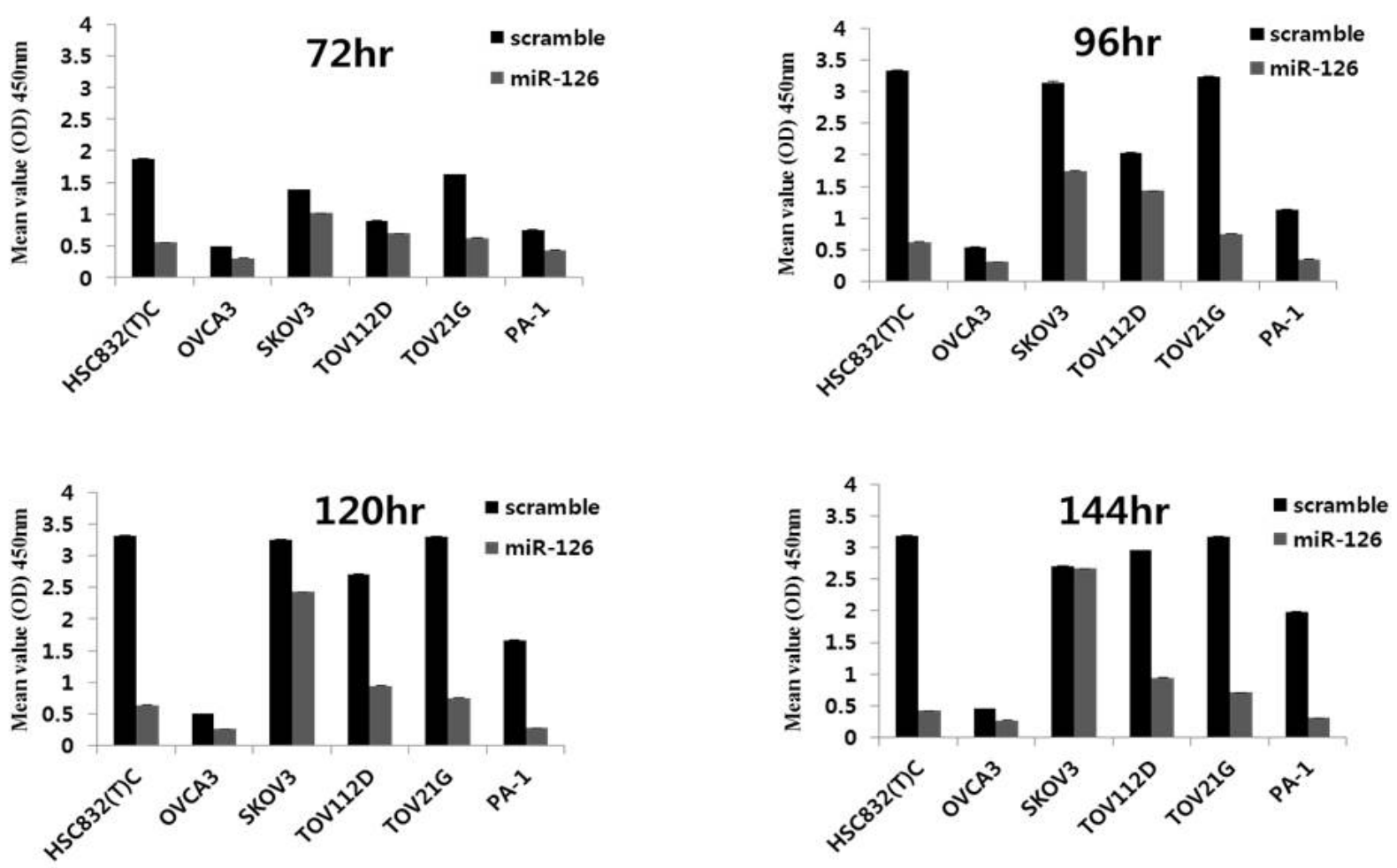

Fig. 4. Cell proliferation analysis using CCK8 after scramble and microRNA-126 treatment on various gyneological tumors. Various Ovarian Tumors were transfected with scramble, microRNA-126 and then cultured for 72, 96, 120 and 144 hours. At each time point, cell proliferation capacity was evaluated by measuring the optical density at $450 \mathrm{~nm}$ using CCK-8 assay. Statistical analysis was performed using the Student t test of Sigmaplot 2001 (Aspire International Software, Ashburn, Va). Pvalues of less than 0.05 were regarded as statistically significant.

2013; Liu 등, 2014; Li 등, 2015).

모든 세포의 분열능은 세포주기 조절인자들(cell cycle dependent kinases)의 능력을 반영하는 것으로, 줄기세포 전사인자 조절 은 종양세포의 세포분열능을 조절하는 것(Becker 등, 2006; Xu 등, 2009; Lin 등, 2012) 뿐만 아니라 세포분열인자는 난소의 원시난포 (primordial follicle) 성숙과 조절에 관여하는 것으로 보고되어 있 다(Park 등, 2006; Park 등, 2008). 특히 줄기세포에서의 분열능 (symmetric and asymmetric division)은 줄기세포의 자가재생과 분화유지 및 분화유도(differentiation lineage)에 직접적으로 관 여하는 것으로 보고되어 있다(Adachi 등, 2010; Ma 등, 2013). 게 다가 줄기세포 분화 단계에서 미분화 전사인자의 발현 조절 이상은 세포주기조절인자의 발현 조절에 영향을 미침으로서 미분화 성질 을 유지하는 종양줄기세포로의 발생 가능성을 반영하는 것으로 보 고되고 있다(Sales 등, 2007). 그러므로 microRNA-126을 이용한 미분화 전사인자 $(S O X 2, \operatorname{Lin} 28)$ 의 발현 감소는 종양세포 분열능력 의 약화를 유도하였을 것으로 생각할 수 있다(Cimadamore 등, 2013; Chien 등, 2015; Zhang 등, 2015).

본 연구에서 Skov3와 Ovcar3는 같은 장액성 난소 선암세포이 다. 하지만 Skov3는 microRNA-126처리시 유일하게 분열능이 감
소되지 않았다(Fig. 4). 이러한 이유 중 하나로, Scramble이 처리된 Skov3의 RT-PCR 결과 SOX2와 Lin28에 대한 유전자 발현을 확인 할 수 없었다. 따라서 Skov3는 microRNA-126이 표적 할 수 있는 유전분자 발현 자체가 없음을 의미한다. 다시 말해 이러한 현상은 고농도의 microRNA-126을 처리하여도 이를 조절할 수 있는 유전 분자 자체가 없다는 것이다. 그러므로 microRNA-126는 Skov3에 효과가 없음을 유추해 볼 수 있다. 향후 이에 대한 실험적 접근법으 로, Skov3가 Context gene로의 작용 가능성에 초점을 두고, 좀 더 다양한 전사인자를 적용해 볼 만한 흥미로운 과제라고 생각한다.

본 연구를 종합적으로 생각해 볼 때 microRNA-126는 Skov3를 제외한 다양한 난소 종양세포에서 SOX2와 Lin28을 표적할 수 있었 다. 그러므로 난소기관 종양세포들의 분열능 억제 및 사멸을 유도 할 수 있는 분자생물학적 단서를 제공하였으며, 유전적 치료 분자 로서의 가능성을 보여주었다.

\section{요 약}

최근 종양을 극복하고자 하는 새로운 접근 방법가운데 하나로, 종양세포내에 발현되는 줄기세포 전사인자들(Oct4, SOx2, KLF4 
and $\operatorname{Lin} 28)$ 을 억제하여 종양을 치료하는 연구들이 증가하고 있다. 본 실험은 미분화 전사인자를 표적(조절)하는 microRNA-126을 이용하여 난소종양세포들(6종: HSC832(t)c, Ovcar3, Skov3, PA-1, TOV21G and Tov112D)들 생존과 성장에 어떠한 생물학적 변화를 유도하는지 연구하였다. Scramble과 microRNA-126를 난소종양세포들에 처리 후 세포모양 관찰결과 Skov3를 제외한 난 소 종양세포들에서 형태학적 모양 변성과 부유현상을 관찰하였다. CCK-8을 이용한 세포분열능 분석에서 Skov3를 제외한 난소 종양 세포들의 분열능력이 점차적으로 감소되는 것을 확인하였다. 특히 Tov112D, Tov21G and PA-1에서 각 시간대별로 뚜렷한 세포분열 능력 감소를 확인할 수 있었다. RT-PCR결과 미분화 전사인자들 (Sox2, Lin28)의 발현감소를 확인할 수 있었다. 이러한 결과들은 microRNA-126이 다양한 난소 종양세포들을 표적하여 세포분열 능과 사멸을 유도할 수 있는 가역적 환경(유전자 발현조절)을 제공 함과 동시에 임상 치료에 대한 분자생물학적 단서를 제공할 수 있 을 것이다.

Acknowledgements: 본 연구는 2015년도 원광보건대학교 교내 연구비에 의해 연구되었으며 이에 감사드립니다.

Funding: None

Conflict of interest: None

\section{References}

1. Adachi K, Nikaido I, Ohta H, Ohtsuka S, Ura H, Kadota M, et al. Context-dependent wiring of Sox2 regulatory networks for self-renewal of embryonic and trophoblast stem cells. $\mathrm{Mol}$ Cell. 2013, 52(3): 380-392.

2. Ann Pietrangelo, Brenda B. Spriggs. The outlook for ovarian cancer: prognosis, life expectancy \& survival rates by stage. http://www.healthline.com/health/cancer/ovarian-cancer-outlook\#Overview1, last visited on 2015, November 19.

3. Becker KA, Ghule PN, Therrien JA, Lian JB, Stein JL, van Wijnen AJ, et al. Self-renewal of human embryonic stem cells is supported by a shortened G1 cell cycle phase. Journal of cellular physiology. 2006, 209(3):883-893.

4. Chien CS, Wang ML, Chu PY, Chang YL, Liu WH, Yu CC, et al. Lin28B/Let-7 regulates expression of Oct4 and Sox2 and reprograms oral squamous cell carcinoma cells to a stem-like state. Cancer Res. 2015, 75(21):2553-2565.

5. Cimadamore F, Amador-Arjona A, Chen C, Huang CT, Terskikh AV. Sox2-Lin28/let-7 pathway regulates proliferation and neurogenesis in neural precursors. Proc Natl Acad Sci. 2013, 110(32):E3017-E30-26.

6. Crawford M, Brawner E, Batte K, Yu L, Hunter MG, Otterson GA, et al. MicroRNA-126 inhibits invasion in non-small cell lung carcinoma cell lines. Biochem Biophys Res Commun. 2008, 373(4):607-612.
7. Eulalio A, Huntzinger E, Nishihara T, Rehwinkel J, Fauser M, Izaurralde E. Deadenylation is a widespread effect of miRNA regulation. $R N A$. 2009, 15(1):21-32.

8. Hamano R, Miyata H, Yamasaki M, Sugimura K, Tanaka K, Kurokawa $\mathrm{Y}$, et al. High expression of Lin28 is associated with tumour aggressiveness and poor prognosis of patients in oesophagus cancer. BrJ Cancer. 2012, 106(8):1415-1423.

9. Ittai BP, Matthew WT, Vincent JC, Ruping G, George WB, Aviv $\mathrm{R}$, et al. An embryonic stem cell-like gene expression signature in poorly differentiated aggressive human tumors. Nature Genetics. 2008, 40:499-507.

10. Li XM, Wang AM, Zhang J, Yi H. Down-regulation of microRNA-126 expression in colorectal cancer and its clinical significance. Med Oncol. 2011, 28(4):1054-1057.

11. Li Y, Chen K, Li L, Li R, Zhang J, Ren W. Overexpression of Sox2 is involved in paclitaxel resistance of ovarian cancer via the PI3K/Akt pathway. Tumour Biol. 2015, 11:1-6.

12. Lin F, Lin P, Zhao D, Chen Y, Xiao L, Qin W, et al. Sox2 targets cyclinE, p27 and survivin to regulate androgen-independent human prostate cancer cell proliferation and apoptosis. Cell Prolif. 2012, 45(3):207-216.

13. Liu B, Peng XC, Zheng XL, Wang J, Qin YW. MicroRNA-126 restoration down-regulate VEGF and inhibit the growth of lung cancer cell lines in vitro and in vivo. Lung Cancer. 2009, 66(2):169-175.

14. Liu LY, Wang W, Zhao LY, Guo B, Yang J, Zhao XG, et al. MicroRNA-126 inhibits growth of SGC-7901 cells by synergistically targeting the oncogenes PI3KR2 and Crk, and the tumor suppressor PLK2. Int J Oncol. 2014, 45(3):1257-1265.

15. Luo P, Fei J, Zhou J, Zhang W. microRNA-126 suppresses PAK4 expression in ovarian cancer SKOV3 cells. Oncol Lett. 2015, 9(5):2225-2229.

16. Ma W, Ma J, Xu J, Qiao C, Branscum A, Cardenas A, et al. Lin28 regulates BMP4 and functions with Oct4 to affect ovarian tumor microenvironment. Cell Cycle. 2013, 12(1):88-97.

17. McLean K, Gong Y, Choi Y, Deng N, Yang K, Bai S, et al. Human ovarian carcinoma-associated mesenchymal stem cells regulate cancer stem cells and tumorigenesis via altered BMP production. J Clin Invest. 2011, 121(8):3206-3219.

18. Nguyen LV, Vanner R, Dirks P, Eaves CJ. Cancer stem cells: an evolving concept. Nat Rev Cancer. 2012, 12:133-143.

19. Otsubo T, Akiyama Y, Hashimoto Y, Shimada S, Goto K, Yuasa Y. MicroRNA-126 inhibits Sox2 expression and contributes to gastric carcinogenesis. PLoS One. 2011, 6(1):e16617.

20. Peng S, Maihle NJ, Huang Y. Pluripotency factors Lin28 and Oct4 identify a sub-population of stem cell-like cells in ovarian cancer. Oncogene. 2010, 29(14):2153-2159.

21. Park CE, Hong SN. Expression patterns of cell cycle related genes mRNA and proteins in the mouse ovary. Korean J Clin Lab Sci. 2006, 38:72-81.

22. Park CE, Kim DJ, Hong SN. Expression of mRNAs and proteins of cyclin A and LATS genes in ovary. Korean J Clin Lab Sci. 2008, 40:31-40.

23. Saito Y, Friedman JM, Chihara Y, Egger G, Chuang JC, Liang G. Epigenetic therapy upregulates the tumor suppressor microRNA-126 and its host gene EGFL7 in human cancer cells. Biochem Biophys Res Commun. 2009, 379(3):726-731. 
24. Sales KM, Winslet MC, Seifalian AM. Stem cells and cancer: an overview. Stem Cell Rev. 2007, 3(4): 249-255.

25. Schoenhals M, Kassambara A, De Vos J, Hose D, Moreaux J, Klein B. Embryonic stem cell markers expression in cancers. Biochem Biophys Res Commun. 2009, 383(2):157-162.

26. Shen WF, Hu YL, Uttarwar L, Passegue E, Largman C. MicroRNA-126 regulates HOXA9 by binding to the homeobox. Mol Cell Biol. 2008, 28(14):4609-4619.

27. Sun Y, Bai Y, Zhang F, Wang Y, Guo Y, Guo L. microRNA-126 inhibits non-small cell lung cancer cells proliferation by targeting EGFL7. Biochem Biophys Res Commun. 2010, 391(3):14831489.

28. Viswanathan SR, Powers JT, Einhorn W, Hoshida Y, Ng TL, Toffanin S, et al. Lin28 promotes transformation and is asso- ciated with advanced human malignancies. Nat Genet 2009, 41: 843-848.

29. Williams AE. Functional aspects of animal microRNAs. Cell. Mol. Life Sci. 2008, 65(4):545-562.

30. Xu B, Zhang K, Huang Y. Lin28 modulates cell growth and associates with a subset of cell cycle regulator mRNAs in mouse embryonic stem cells. RNA. 2009, 15:357-361.

31. Zhang J, Du YY, Lin YF, Chen YT, Yang L, Wang HJ, et al. The cell growth suppressor, microRNA-126, targets IRS-1. Biochem Biophys Res Commun. 2008, 377(1):136-140.

32. Zhang Q, Zeng $\mathrm{S}$, Quan C, Lin X. Induction function of microRNA-126 in survival and proliferation in neural stem cells. Med Sci Monit. 2015, 21:3023-3027. 